\title{
Urgences
}

\section{Mes mots forment des ronds dans l'eau...}

\section{Marie-Andrée Massicotte}

Numéro 1, 2e trimestre 1981

URI : https://id.erudit.org/iderudit/025012ar

DOI : https://doi.org/10.7202/025012ar

Aller au sommaire du numéro

Éditeur(s)

Urgences

ISSN

0226-9554 (imprimé)

1927-3924 (numérique)

Découvrir la revue

Citer ce document

Massicotte, M.-A. (1981). Mes mots forment des ronds dans l'eau... Urgences, (1), 66-70. https://doi.org/10.7202/025012ar d'utilisation que vous pouvez consulter en ligne.

https://apropos.erudit.org/fr/usagers/politique-dutilisation/ 


\section{Marie-Andrée Massicotte}


Mes mots forment des ronds dans l'eau

et la pierre plate de mes phrases

touche l'air, touche l'eau

rebondit, forme sillage et se confond au coeur de l'eau

L'eau profonde et verte

germes de vie en dérive

limpidité en perte

tant de déchets sur la rive

Ce siècle forme des ronds dans l'eau

la pierre lourde de ses plaisirs

suinte l'écume verte de sa perte

atteint la terre, gruge le temps

pour satisfaire tous les désirs

de confort et d'argent

touche l'air, touche l'eau

rebondit, sème la rage

éteint le vrai, éteint le beau

ce siècle ne vit que de mirages

il n'y a plus d'air, il n'y a plus d'eau

mes mots tombent dedans la vase

sèchent en petites pierres plates

pour se languir en dentelles vagues

Dans le jour de ma phrase

se construit l'énorme tour de Babel

issue d'un seul et même langage

écrasant de non-sens l'extase

nous reléguant dans l'irréel

Et le mot et le geste sont jeux cruels

La pierre plate de mes phrases s'érosionne en larmes de sel... 
Ah !... Connaître un jour un chiromancien sachant lire entre les lignes de la main

Ah! la bonne aventure... 
Le ciel a forme d'oiseau

derrière son oeil de nacre

la nuit a forme d'oiseau

le vent dans ses ailes craque

J'ai su que vue de là-haut

la vie a forme de nuage

avec ou sans équipage

la vie a forme de bateau

Et vogue vogue la galère

quand donc s'apaisera misère

douceur s'envola tant tôt

la nuit avait forme d'oiseau 
Bien sûr, il y a des moments qui se voudraient éternels bien sûr, le tic-tac des heures inéluctablement poursuit

mêlé aux bruissements du coeur

sa route

Les mondes tissés par l'imaginaire s'entremêlent au quotidien pour rapiécer des jours en lambeaux déjà

Qu importe l'inaccessible, le regard qui revient, la vie vécue d'avance

Prenez votre temps, je prends ma course

Nous qui sommes des morts en sursis

comme les parallèles nos appartenances sont au chaud dans l'infini 